\title{
Pulmonary Uptake of Liposomal Phosphatidylcholine
}

\author{
RICHARD D. ZACHMAN ${ }^{(29)}$ AND FRANCIS H. C. TSAO \\ Department of Pediatrics of the University of Wisconsin, and the Wisconsin Perinatal Center, Madison, Wisconsin,

\section{Summary}

Liposomes prepared with phosphatidylcholine (PC) labeled with $\left[1-{ }^{14} \mathrm{C} \mid\right.$-dipalmitoyl-PC, dicetylphosphate, cholesterol (molar ratio 7:2:1) were injected into the right ear vein of 2 -month-old male rabbits. At 5, 60, and $120 \mathrm{~min}$ after injection, organs were removed and analyzed for $\left[{ }^{14} \mathrm{C}-\mathrm{PC}\right.$. Lung, liver, and spleen took up the $\left[{ }^{14} \mathrm{C}\right]-\mathrm{PC}$ by $5 \mathrm{~min}$. Spleen accumulation of $\left[{ }^{14} \mathrm{C}\right]-\mathrm{PC}$ increased steadily, liver plateaued from 1-2 hr, and lung fell rapidly. The uptake of liposomal $\left[{ }^{14} \mathrm{C} \mid-\mathrm{PC}\right.$ by lung and liver was dependent on the concentration of iv injected liposomal $\left[{ }^{14} \mathrm{C}\right]-\mathrm{PC}$. All lung subcellular fractions (lamellar bodies, mitochondria, and microsomes) took up $\left[{ }^{14} \mathrm{C}\right]-\mathrm{PC}$. Lamellar body $\left[{ }^{14} \mathrm{C}\right]-\mathrm{PC}$ was highest at $5 \mathrm{~min}$, and then decreased. Still, on a nmole/mg protein basis, uptake of $\left[{ }^{14} \mathrm{C}\right]-\mathrm{PC}$ by lamellar bodies was higher than other organelle fractions. Of the radioactivity in lung, $95 \%$ was $\left[{ }^{14} \mathrm{C}\right]-\mathrm{PC}$ even after $2 \mathrm{hr}$, whereas by $1 \mathrm{hr}, 28 \%$ of liposomal PC absorbed by liver had been degraded.

\section{Speculation}

Neonatal respiratory distress syndrome (RDS) is clearly related to alveolar lining surfactant deficiency. PC is quantitatively the principal phospholipid of that surfactant. If iv injected PC in the form of liposomes (large multilamellar concentric bilayer vesicles) can be taken up by lung lamellar bodies, it is possible that this PC will then be available for release to the alveolar surface. This potentially might become a unique biochemical approach in the therapy of neonatal RDS.

PC, especially dipalmitoyl-PC, is quantitatively the major lipid component of alveolar lining surfactant $(6,16)$, and is significantly lacking in neonatal RDS (5). This most abundant disaturated-PC is stored in the lamellar bodies of type II alveolar epithelial cells. It is then secreted to participate in forming a surface-active lining at the air-alveolar surface that stabilizes the lung and aids respiration $(5,7)$. There is extensive research attempting to define the mechanisms of PC biosynthesis and turnover in lung (26).

Presently, the usual treatment approach for RDS is supportive neonatal intensive care methods (5), in conjunction with assisted ventilation and end positive pressure for hypoxia and ventilatory failure. Antenatal maternal steroid administration to enhance fetal lung maturation and prevent neonatal RDS in the premature is now receiving considerable support and initial reports show promise $(14,18,20,22,23)$. Recent approaches have attempted to deposit surfactant onto the alveolar surface by pharyngeal or tracheal instillation, using positive pressure ventilation of aerosolized synthetic PC, aerosolized PC extracted from lungs, and sonicated PC (10, 11, 17, 19).

When phospholipids are suspended in an excess of aqueous solution, they spontaneously form liposomes. Liposomes are multilamellar concentric bilayer vesicles with the lipid layers separated by aqueous medium (25). Liposomes have been extensively studied as models for biologic membranes (1) or as carrier vehicles for introducing into cells membrane impermeable substances such as enzymes, chelating agents, hormones, and antitumor drugs either by membrane fusion or phagocytosis $(8,9,25)$.

The purpose of the experiments reported here was to test the hypothesis that iv administered liposomal PC could be taken up by lung lamellar bodies. To date, there was no previous work addressing that question. In this study, it was found that is administered liposomal PC was taken up by lung subcellular fractions, including lamellar bodies.

\section{MATERIALS AND METHODS}

\section{MATERIALS}

$\left[1-{ }^{14} \mathrm{C}\right]$-Dipalmitoyl-PC was purchased from Applied Science Laboratories, Inc. (State College, PA). Dicetylphosphate (dihexadecanoyl phosphate) was obtained from Sigma Chemical Co. (St. Louis, MO). Cholesterol was the product of Supelco, Inc (Bellefonte, PA). Bovine serum albumin (fraction V) was purchased from Miles Laboratories, Inc. (Kankakee, Ill.). All other chemicals and solvents are reagent grade.

\section{PREPARATION OF LIPOSOMES}

Egg PC was isolated from lyophilized egg yolk and purified by aluminum oxide and silicic acid columns (1). Egg yolk PC purity was examined by thin-layer chromatography (TLC) with a developing solvent of chloroform:methanol:water (65:25:4). Purity of the radioactively labeled PC was also assured by TLC, and the fatty acid moieties of $\mathrm{PC}$ were confirmed by gas-liquid chromatography. A mixture of PC, dicetylphosphate, and cholesterol in a molar ratio of 7:2:1 was used for liposome preparation (21). The lipids containing $10 \mu$ mole PC labeled with $\left[1-{ }^{14} \mathrm{C}\right]$-dipalmitoylPC (10 $\mu \mathrm{ci})$ were dissolved in $1 \mathrm{ml}$ chloroform, and the solvent was evaporated to dryness under nitrogen while the tube was being rotated. The lipids that formed a thin film on the wall of the tube were then suspended in $1 \mathrm{ml}$ water; the tube was shaken by hand frequently for $1-2 \mathrm{hr}$ at room temperature $\left(20-25^{\circ}\right)$. The true specific radioactivity of liposomal PC was determined by analyzing the radioactivity and concentration of PC isolated from TLC. The radioactivity of PC recovered from TLC was measured in $10 \mathrm{ml}$ scintillation solution $(3.3 \mathrm{~g} \mathrm{3,5-diphenyloxazole} \mathrm{in} 400 \mathrm{ml}$ toluene, plus $200 \mathrm{ml}$ ethylene glycol monoethyl ether) with a Beckman CMP-100 liquid scintillation counter. The concentration of PC isolated from TLC was determined by measuring its phosphorus content (3) in the presence of silica gel (24). The specific radioactivity of liposomal PC was expressed as cpm per nmole PC. The average specific radioactivity from four preparations was $1581 \pm 82 \mathrm{cpm} / \mathrm{nmole}$ PC (mean $\pm \mathrm{SD}$ ).

The size of hand shaken liposomes are about $1 \mu$ meter in diameter, but multilamellar liposomes do not always have a uniform size population $(1,25)$. However, the possible heterogeneity of the liposomes was not important at this time and was not determined.

In the pilot study, the stability of liposomes at $37^{\circ}$ was tested. 
Liposomes were prepared in $0.3 \mathrm{M}$ glucose and dialyzed against isotonic buffer of $0.075 \mathrm{M} \mathrm{KCl}$ and $0.075 \mathrm{M} \mathrm{NaCl}$ at room temperature for $16 \mathrm{hr}$. The dialyzed liposomes were then incubated at $37^{\circ}$. Glucose that escaped from liposome and that which was entrapped in liposomes was measured by the change in absorbance at $340 \mathrm{NM}$ with a Beckman DUR spectrophotometer. The assay was carried out in a $10 \mathrm{~mm}$. light path curvette containing the following reagents $(4,13): 0.28 \mathrm{ml} 0.1 \mathrm{M}$ Tris $\mathrm{HCl}$ buffer $(\mathrm{pH} 8.0)$; $0.5 \mathrm{ml}$ double strength isotonic solution $(0.15 \mathrm{M} \mathrm{KCl}$ and $0.15 \mathrm{M}$ $\mathrm{M} \mathrm{NaCl}) ; 0.1 \mathrm{ml}$ magnesium acetate $(0.02 \mathrm{M}) ; 0.05 \mathrm{ml} \mathrm{ATP}(0.02$ $\mathrm{M}) ; 0.05 \mathrm{ml} \mathrm{NADP}{ }^{+}(0.01 \mathrm{M}) ; 5 \mu \mathrm{l}$ hexokinase $(0.7 \mathrm{mg}$ protein/ $0.1 \mathrm{ml}) 5 \mu \mathrm{l}$ glucose- 6 -phosphate dehydrogenase $(0.3 \mathrm{mg}$ protein/ $0.1 \mathrm{ml}$ ). All reagents were prepared in Tris buffer. The reaction was initiated by the addition of $5 \mu \mathrm{l}$ of liposomes. After a stable change in absorbance was observed, $0.01 \mathrm{ml}$ of $25 \%$ Triton X-100 solution in Tris buffer was added to the curvette to disrupt the liposome and release the remaining entrapped glucose. After $2 \mathrm{hr}$ incubation at $37^{\circ}$, no significant amount of glucose had leaked out from liposomes.

\section{ANIMAL INJECTION}

Two-month-old rabbits were given an iv bolus injection in the right ear with $0.5 \mathrm{ml}$ liposomes labeled with $\left[{ }^{14} \mathrm{C}\right]$-dipalmitoyl PC. After various times, the rabbits were killed and the tissues were removed and analyzed for $\left[{ }^{14} \mathrm{C}\right]-\mathrm{PC}$. Lungs and livers were perfused intravascularly with cold saline to remove blood until the tissue was uniformly bloodless (white for lungs, pale brown for liver). Kidney, heart, spleen, and about $10 \mathrm{~cm}$ small intestine were also removed and rinsed with ice cold saline. Two g of each tissue sample was then homogenized in $6 \mathrm{ml}$ cold $0.33 \mathrm{M}$ sucrose- $0.01 \mathrm{M}$ Tris $\mathrm{HCl}$ buffer $(\mathrm{pH} \mathrm{7.4)}$ in a Potter-Elvehjem homogenizer (clearance $0.005-0.007$ inch) with six strokes at low speed. The homogenate was filtered through one layer of cheesecloth. Subcellular fractions of lung including lamellar bodies, mitochrondria, microsomes, and cytosol were isolated by the method of sucrose gradient described previously (24) and analyzed for $\left[{ }^{14} \mathrm{C}\right]-\mathrm{PC}$.

\section{ANALYSIS OF PHOSPHOLIPIDS AND PROTEIN}

Lipids in the homogenate of each organ and subcellular fractions of lung were extracted by the method of Bligh and Dyer (2). PC was quantitatively isolated by TLC, and its radioactivity and concentration were measured as described previously.

The distribution of radioactivity in fatty acid moieties at the 1and 2-positions of PC in liposomes, lung homogenate, and subcellular fractions was also analyzed in one experiment. PC was first separated by TLC with the developing solvent of chloroform: methanol:water $(65: 25: 4)$. The TLC plate $(20 \times 20 \mathrm{~cm})$ was then gently stained in iodine vapor for a few sec. The PC on the TLC plate was then hydrolyzed by $40 \mu \mathrm{l}$ Crotalus adamanteus venom phospholipase $\mathrm{A}_{2}$ (about $100 \mu \mathrm{g}$ in $50 \mu \mathrm{l} 0.05 \mathrm{M}$ Tris $\mathrm{HCl}$ buffer containing $10 \mathrm{mM} \mathrm{Ca}^{2+}, \mathrm{pH} 8.0$ ) which was partially purified from Sephadex G-100 and DEAE-cellulose column chromatography (27). After the PC spot on the silica gel was completely dry, the TLC plate was subjected to a second dimensional development in the same developing solvent. Radioactivities of fatty acid, PC, lysoPC, and the background corresponding to the same size of these spots between the solvent front and the origin were determined.

The protein concentration of the tissue homogenate and the subcellular fractions was determined by the method of Lowry et al. (15); bovine serum albumin was used as a standard.

\section{RESULTS}

Lung, liver, and spleen took up iv injected liposomal $\left[{ }^{14} \mathrm{C}\right]-\mathrm{PC}$ rapidly. The amount of $\left[{ }^{14} \mathrm{C}\right]-\mathrm{PC}$ accumulated in each organ was time dependent (Fig. 1). Lung uptake of liposomal $\left[{ }^{14} \mathrm{C}\right]-\mathrm{PC}$ was very rapid and as active on a nmole/mg protein basis as liver and spleen. However, in contrast to liver and spleen, lung uptake or accumulation of $\left[{ }^{14} \mathrm{C}\right]-\mathrm{PC}$ decreased after the initial rapid appear-

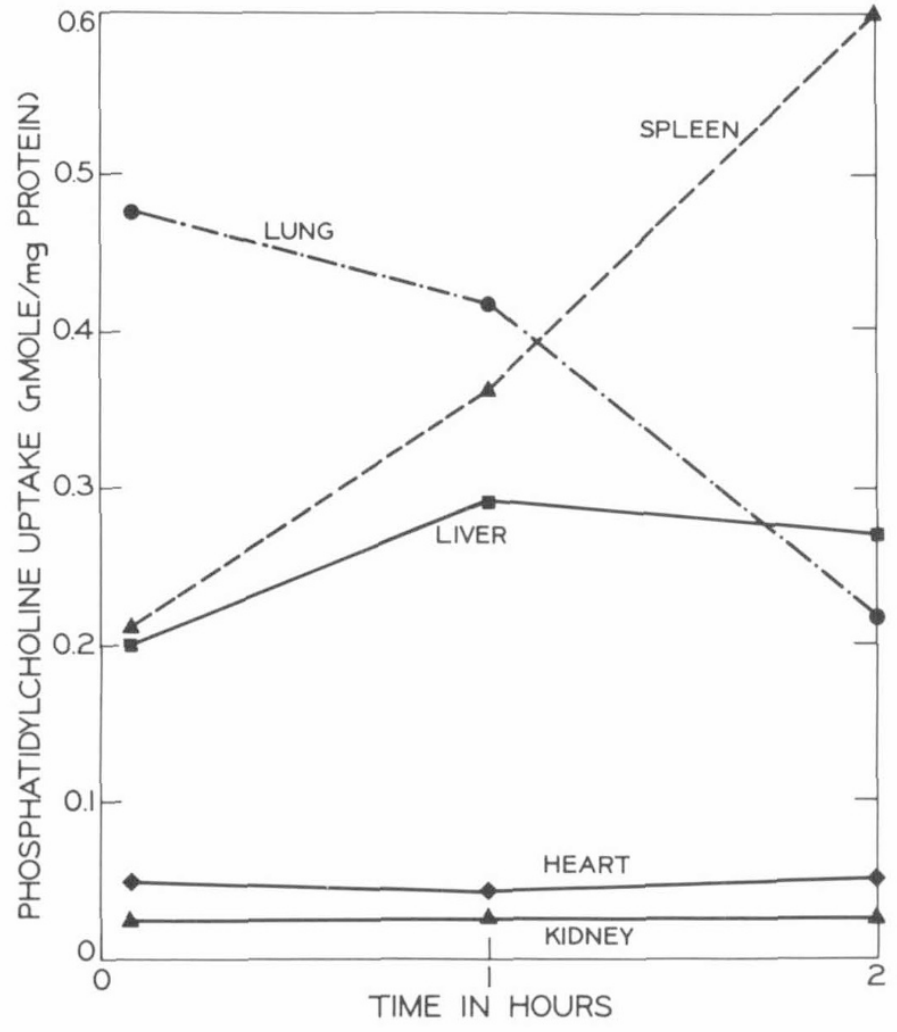

Fig. 1. Uptake of liposomal $\left[{ }^{14} \mathrm{C}\right]-\mathrm{PC}$ by rabbit tissues. A bolus of liposomal $\left[{ }^{14} \mathrm{C}\right]-\mathrm{PC}$ was injected in a right ear vein. At the times indicated, tissues were removed, and the $\left[{ }^{14} \mathrm{C}\right]-\mathrm{PC}$ was determined as described in Methods. The data is the mean of two separate experiments.

ance. Heart, kidney, and small intestine had relatively little $\left[{ }^{14} \mathrm{C}\right]-\mathrm{PC}$ uptake and no time dependency was noted. Blood concentration of liposomal $\left[{ }^{14} \mathrm{C}\right]-\mathrm{PC}$ decreased $60 \%$ by 5-30 min after injection. The uptake (nmole $\left[{ }^{14} \mathrm{C}\right]-\mathrm{PC} / \mathrm{mg}$ tissue $/ 5 \mathrm{~min}$ ) by lung and liver was linearally dependent upon the concentration of the iv injected liposomal $\left[{ }^{14} \mathrm{C}\right]-\mathrm{PC}$ (Fig. 2). This uptake vs. concentration relationship was 3.5 -fold greater in lung than liver.

$\left[{ }^{14}\right] \mathrm{C}-\mathrm{PC}$ appeared in all lung subcellular fractions after liposomal $\left[{ }^{14} \mathrm{C}\right]-\mathrm{PC}$ injection (Fig. 3). On a nmole/mg protein basis, lamellar body liposomal $\left[{ }^{14} \mathrm{C}\right]$-PC uptake was higher than other subcellular fractions. The low protein content of lamellar bodies accounts for a high specific activity.

An effort was made to determine if some of the $\left[{ }^{14} \mathrm{C}\right]-\mathrm{PC}$ found in subcellular fractions might be from nonspecific adsorption of liposomal $\left[{ }^{14} \mathrm{C}\right]-\mathrm{PC}$ to subcellular particles. Liposomal PC was added to a fresh chilled lung homogenate, then subcellular fractionation was carried out immediately. The amount of $\left[{ }^{14} \mathrm{C}\right]-\mathrm{PC}$ added was similar to the total $\left[{ }^{14} \mathrm{C}\right]-\mathrm{PC}$ found in lung from the in vivo injections. The values for nonspecific adsorption determined by this method were: lamellar bodies, $0.84 \pm 0.51 \mathrm{nmole} P C / \mathrm{mg}$ protein; mitochondria, $0.12 \pm 0.2$; and microsomes, $0.25 \pm 0.01$. These are far below the actual amounts found in subcellular fractions from in vivo injections (Fig. 3).

The ${ }^{14} \mathrm{C}$ radioactivity distribution in lipid fractions of lung and liver is shown in Table 1 . Lung radioactivity was still $95 \%\left[{ }^{14} \mathrm{C}\right]-$ PC, even after $2 \mathrm{hr}$, but $28 \%$ of liver radioactivity was present in free fatty acids, neutral lipid, or other unidentified lipids. At all times, lamellar body radioactivity was $99-100 \%$ as $\left[{ }^{14} \mathrm{C}\right]-\mathrm{PC}$. The percent of $\mathrm{PC}$ radioactivity in the other lung subcellular fractions ranged from $90-95 \%$, and no consistent change with time was noted.

\section{DISCUSSION}

Liposomes have recently been extensively used as carrier vehicles for introducing membrane impermeable substances into cells. 


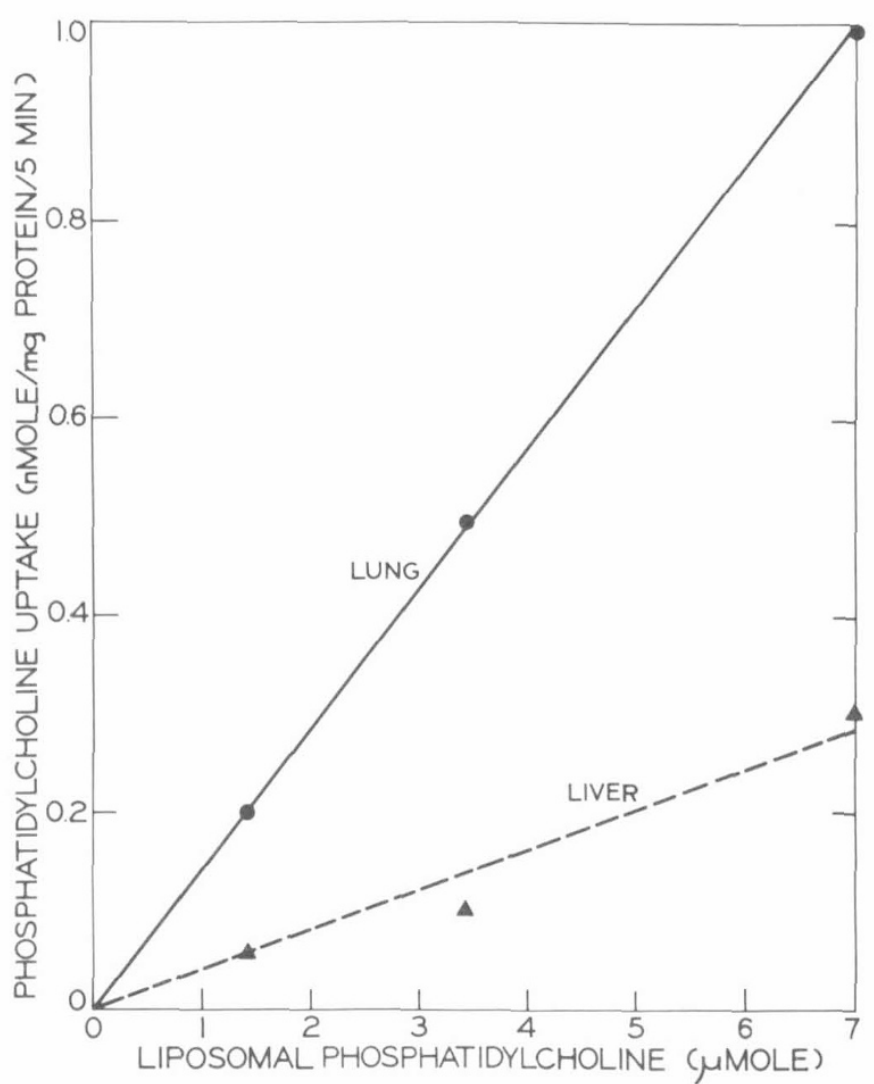

Fig. 2. Effect of liposomal PC concentration on uptake of PC by lung and liver. Liposomal $\left[{ }^{14} \mathrm{C}\right]-\mathrm{PC}$ at three concentrations was injected into three separate rabbits. Five min after each injection, the lung and liver of each animal were removed and analyzed for $\left[{ }^{14} \mathrm{C}\right]-\mathrm{PC}$.

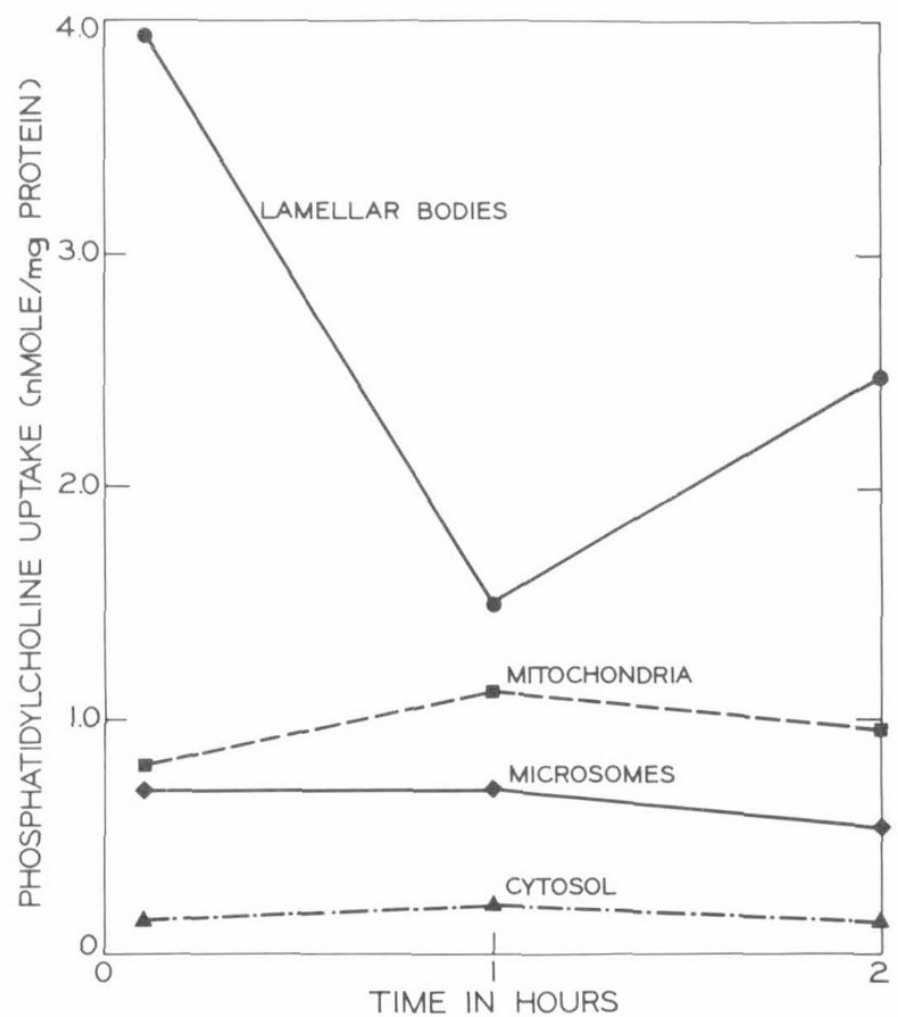

Fig. 3. Uptake of liposomal $\left[{ }^{14} \mathrm{C}\right]-\mathrm{PC}$ by subcellular fractions. After ear vein injection of liposomal $\left[{ }^{14} \mathrm{C}\right]-\mathrm{PC}$, lungs were removed at various times, and the $\left[{ }^{14} \mathrm{C}\right]-\mathrm{PC}$ of the various subcellular fractions was determined as described in Methods. The data is the mean of two separate experiments.
After entry into the target cells, the liposome is then broken down by intracellular lysosomal enzyme activity, thereby releasing the liposome-entrapped substance and allowing it to enter metabolic pathways of the cell. To date, few studies have been done on pulmonary uptake of liposomes (25) and there has been no study of the delivery of lipsomes to lung subcellular organelles.

The authors demonstrated that iv administered liposomal PC could be taken up by lung lamellar body. Lung, on a per mg protein basis, was as active as liver and spleen in taking up liposomal $\left[{ }^{14} \mathrm{C}\right]-\mathrm{PC}$. However, the kinetics of the liposomal $\left[{ }^{14} \mathrm{C}\right]-$ $\mathrm{PC}$ uptake and accumulation by lung was significantly different from that of other organs. Studies by others have shown that liver and spleen readily take up liposomes (25), apparently because of their active reticuloendothelial systems. Hence, the injections of liposomal $\left[{ }^{14} \mathrm{C}\right]-\mathrm{PC}$ here were given in the ear vein. That approach was chosen to insure that the liposomes would initially be distributed to the pulmonary circulation before being circulated through the portal, hepatic, and splenic vasculature, with a subsequent loss of significant amounts of material.

The disappearance of radioactivity from lung, after the initial rapid uptake, is not understood. $\left[{ }^{14} \mathrm{C}\right]$-Ethylaminetetraacetic acid entrapped in liposomes is taken up by lung with a similar kinetic pattern, but was not explained by Jonah et al. (12). The disappearance of $\left[{ }^{14} \mathrm{C}\right]-\mathrm{PC}$ from lung noted here might represent turnover of $\left[{ }^{14} \mathrm{C}\right]-\mathrm{PC}$. However, the authors do not have evidence of a significant amount of degradation of $\left[{ }^{14} \mathrm{C}\right]-\mathrm{PC}$ in lung. The lipid radioactivity in lung even after $120 \mathrm{~min}$, was still $95 \%$ as $\left[{ }^{14} \mathrm{C}\right]-\mathrm{PC}$, in contrast to liver. In liver, nearly $30 \%$ of the $\left[{ }^{14} \mathrm{C}\right]-\mathrm{PC}$ had been broken down by $60 \mathrm{~min}$ after injection (Table 1). Another possible explanation for the disappearance of lung $\left[{ }^{14} \mathrm{C}\right]-\mathrm{PC}$ with time could be that it was being secreted onto the airway surface, migrating to upper airways, and was subsequently not included in lung homogenization. Preliminary tracheal wash experiments suggest this might be occurring, but more work is needed to prove the point.

Lung uptake of liposomal-PC appears active and valid by several criteria. The uptake was concentration dependent (Fig. 2). Intracellular distribution of the accumulated liposomal $\left[{ }^{14} \mathrm{C}\right]-\mathrm{PC}$ into all subcellular fractions was demonstrated (Fig. 3). The method used here for subcellular fractionation contains minimum cross contamination of the subcellular particles (24). Finally, an in vitro experiment suggests that nonspecific adsorption of liposomal $\left[{ }^{14} \mathrm{C}\right]-\mathrm{PC}$ could only account for $10-25 \%$ of the $\left[{ }^{14} \mathrm{C}\right]-\mathrm{PC}$ in subcellular fractions. It might be possible that liposomes are "sticking" to the vascular bed of the lung and are not really being incorporated into cells. However, as just mentioned, the authors have checked for nonspecific adsorption in vitro and there is little. Additionally, in experiments including zero time, when blood is highest in liposomal $\left[{ }^{14} \mathrm{C}\right]-\mathrm{PC}$, the lung $\left[{ }^{14} \mathrm{C}\right]-\mathrm{PC}$ was much lower than the 5 min values, which again supports active lung uptake.

The possibility exists that liposomal $\left[{ }^{14} \mathrm{C}\right]-\mathrm{PC}$ is degraded and the free fatty acids reincorporated into lung $\mathrm{PC}$ during this experiment. However, when lung PC isolated from these experiments was subjected to hydrolysis with snake venom phospholipase $A_{2}$, the ratio of $\left[{ }^{14} \mathrm{C}\right]$-fatty acids (free fatty acid:fatty acid in the lysoPC) was near unity for each time period. Although this does not absolutely rule out some hydrolysis and resynthesis during the experiment, this possibility is unlikely.

In summary, liposomal $\left[{ }^{14} \mathrm{C}\right]-\mathrm{PC}$ injected into the ear vein of 2month-old rabbits is rapidly and actively taken up by lung. A significant amount of that $\left[{ }^{14} \mathrm{C}\right]-\mathrm{PC}$ appears in the lamellar body fraction. The radioactivity in lamellar bodies disappears with time, but remains predominantly $\left[{ }^{14} \mathrm{C}\right]-\mathrm{PC}$ for at least $2 \mathrm{hr}$. The rapid disappearance of $\left[{ }^{14} \mathrm{C}\right]-\mathrm{PC}$ from lung in these experiments is not understood. IV injection of liposomal-PC to deliver PC to lung lamellar bodies as described here needs to be compared with other methods, such as using precursor incorporation or other PC solubilization and suspension methods. These questions require further investigation. 
Table 1. Distribution of radioactivity in tissue and subcellular fractions derived from liposomal- $C^{14} P C$

$\%$ Radioactivity as $\mathrm{C}^{14}$-PC

Time after injection $(\mathrm{min})$

Liver Lung

\begin{tabular}{rccccccc}
\cline { 2 - 5 } & Whole homogenate & Whole homogenate & Lamellar bodies & Mitochondria & Microsomes & Soluble \\
\hline 5 & 93.6 & 95.6 & 100 & 94.8 & 91.6 & 94.7 \\
60 & 72.5 & 95.2 & 99.3 & 93.0 & 94.5 & 91.0 \\
120 & 72.2 & 95.4 & 99.2 & 90.4 & 90.9 & 95.9 \\
\hline
\end{tabular}

\section{REFERENCES AND NOTES}

1. Baugham, A. D., Hill, M. W., and Miller, N. G. A.: Preparation and use of liposomes as models of biological membrane. In: E. D. Korn: Methods in Membrane Biology. Vol. 1, p. 1 (Plenum Press, New York, 1974).

2. Bligh, E. G., and Dyer, W. J.: A rapid method of total lipid extraction and purification. Can. J. Biochem. Physiol., 37: 911 (1959).

3. Chen, P. S., Toribara, T. Y., and Warner, H.: Microdetermination of phosphorus. Anal. Chem., 28: 1756 (1956)

4. Damel, R. A., Kinsky, S. C., Kinsky, C. B., and Van Deenen, L. L. M.: Effects of temperature and cholesterol on the glucose permeability of liposomes prepared with natural and synthetic lecithins. Biochim. Biophys. Acta, 150: 655 (1968).

5. Farrell, P. M., and Avery, M. E.: Hyaline membrane disease. Amer. Rev. Respir. Dis., 111: 657 (1975).

6. Finley, T. N., Morgan, T. E., Fialkow, H. C., and Huber, G. L.: Surface activity of phospholipid components of dog pulmonary surfactant collected in vivo. Fed. Proc., 23: 156 (1964).

7. Frosolono, M. F.: Lung. In: F. Snyder: Lipid Metabolism in Mammals. Vol. 2, p. 1 (Plenum Press, New York, 1977).

8. Gregoriadis, G.: The carrier potential of liposomes in biology and medicine. Part 1. N. Engl. J. Med., 295: 704 (1976).

9. Gregoriadis, G.: The carrier potential of liposomes in biology and medicine. Part 2. N. Engl. J. Med. 295: 765 (1976).

10. Ikegami, M., Hesterberg, T., Nozaki, M., and Adams, F. H.: Restoration of lung pressure-volume characteristics with surfactant: Comparison of nebulization versus instillation and natural versus synthetic surfactant. Pediatr. Res., 11: 178 (1977).

11. Ivey, H., Roth, S., Kattwinkel, J.: Nebulization of sonicated phospholipids (pL) for treatment of Respiratory Distress Syndrome (RDS) of infancy. Pediatr. Res. (Abstract), 11: 573 (1977).

12. Jonah, N. M., Cerny, E. A., and Rehman, Y. E.: Tissue distribution of EDTA encapsulated within liposomes of varying surface properties. Biochim. Biophys. Acta, 401: 336 (1975)

13. Kinsky, S. C., Haxby, J., Kinsky, C. B., Demel, R. A., and Van Deenen, L. L. M.: Effect of cholesterol incorporation on the sensitivity of liposomes to the polyeneantibiotic filipin. Biochim. Biophys. Acta, 152: 174 (1968).

14. Liggins, G. C., and Howie, R. N.: The prevention of RDS by maternal steroid therapy. In: L. Gluck: Modern Perinatal Medicine. p. 415 (Year Book Medical Publishers, Inc., Chicago, 1974).

Copyright (C) 1980 International Pediatric Research Foundation, Inc. $0031-3998 / 80 / 1401-0024 \$ 02.00 / 0$
15. Lowry, O. H., Rosebrough, N. J., Farr, A. L., and Randall, R. J.: Protein measurement with the Folin phenol reagent. J. Biol. Chem., 193: 165 (1951).

16. Morgan, T. E., Finley, T. N., and Fialkow, H. C.: Comparison of the composition and surface activity of "alveolar" and whole lung lipids in the dog. Biochim. Biophys. Acta, 106: 403 (1965).

17. Nilsson, R., Grossman, G., and Robertson, B.: Lung surfactant and the pathogenesis of neonatal bronchiolar lesions induced by artificial ventilation. Pediatr. Res., 12: 249 (1978).

18. Papageorgiou, A. N., Desgranges, M. F., Masson, M., Colle, E., Shatz, R., and Gelford, M. M.: The antenatal use of betamethazone in the prevention of respiratory distress syndrome: a controlled double-blind study. Pediatrics, 63: 73 (1979).

19. Robertson, B., and Enhorning, G.: The alveolar lining of the premature newborn rabbit after pharyngeal deposition of surfactant. Lab. Invest., 31: 54 (1974).

20. Ross Conferences on Pediatric Research: Lung Maturation and the Prevention of Hyaline Membrane Disease. (1975).

21. Sessa, G., and Weissmann, G.: Incorporation of lysozyme into liposomes. A model for structure-linked latency. J. Biol. Chem., 245: 3295 (1970).

22. Taeusch, H. W., Jr., Frigoletto, R., Kitzmiller, J., Avery, M. E., Hehre, A., Fromm, B., Lawson, E., and Neff, R.: Risk of respiratory distress syndrome after prenatal dexamethazone treatment. Pediatrics, 63: 64 (1979).

23. Thornfeldt, R. E., Franklin, R. W., Pickering, N. A., Amell, G.: The effect of glucocorticoids on the maturation of premature lung membranes. Amer. J. Obstet. Gynecol., 131: 143 (1978).

24. Tsao, F. H. C., and Zachman, R. D.: Phosphatidylcholine-lysophosphatidylcholine cycle pathway enzymes in rabbit lung. I. Subcellular localization and properties. Pediatr. Res., 11: 849 (1977).

25. Tyrrell, D. A., Heath, T. D., Colley, C. M., and Ryman, B. E.: New aspects of liposomes. Biochim. Biophys. Acta, 457: 259 (1976).

26. Van Golde, L. M. G.: Metabolism of phospholipids in the lung. Amer. Rev. Respir. Dis., 114: 977 (1978)

27. Wells, M. A., and Hanahan, D. J.: Studies on phospholipases. I. Isolation and characterization of two enzymes from Crotalus adamanteus venom. Biochemistry, 8: 414 (1969).

28. The authors thank K. Jane Jaskowski, Susan J. Barnard, and Pat W. Cotter for their technical assistance.

29. Requests for reprints should be addressed to: R. D. Zachman, Ph.D., M.D., Department of Pediatrics, University of Wisconsin, and the University of Wisconsin Perinatal Center, 202 S. Park St., Madison, WI 53715 (USA).

30. Received for publication October 11, 1978

31. Accepted for publication January 23, 1979. 